\title{
Effects of nano-curcumin on gene expression of insulin and insulin receptor
}

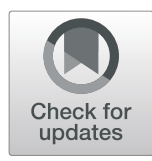

Weaam Gouda ${ }^{\text {* }^{*} \text {, Naglaa A. Hafiz }}{ }^{2}$, Lamiaa Mageed ${ }^{1}$, Ahmed S. Alazzouni ${ }^{3}$, Wagdy K. B. Khalii ${ }^{2}$, Mie Afify ${ }^{1}$ and Mohamed D. E. Abdelmaksoud ${ }^{1}$

\begin{abstract}
Background: This study investigates the effects of nano-curcumin on gene expression of insulin and insulin receptor in diabetic rats. Forty female rats were divided into four groups (ten rats for each). The first group was non-diabetic rats acting as negative control and rats of the second group were rendered diabetic by STZ served as positive controls. The third one was induced diabetic and received oral Diamicron for 3 weeks. The fourth was rendered diabetic and administrated oral nano-curcumin for 3 weeks.

Results: A significant increase of blood glucose was showed in diabetic rats with significant reduction of insulin level compared to non-diabetic controls. The gene expression of insulin and insulin receptor were more significant in diabetic untreated rats compared to the control non-diabetic group. The induction of curcumin as well as Diamicron to diabetic rats normalized significantly their blood sugar level. Also, curcumin-treated rats indicated significant higher in gene expression of insulin and insulin receptor than positive and negative controls.

Conclusion: The results suggest that nano-curcumin could be used as antidiabetic therapy, induced hypoglycemia, and increase the gene expression of insulin and insulin receptor in STZ-induced diabetic rats. More studies are needed to illustrate the definite mechanism of action of nano-curcumin concerning the upregulation of gene expression of the above-mentioned genes.
\end{abstract}

Keywords: Diabetes mellitus, Insulin, Insulin receptor, Gene expression, Nano-curcumin, Rats

\section{Introduction}

The incidence of diabetes is increasing rapidly throughout the last three decades, which is being one of the main epidemic non-communicable diseases. The International Diabetes Federation evaluates that the number of diabetic people reaches 425 million over the world in 2017 and it will increase to 629 million by 2045, indicating a $45 \%$ raise worldwide (Zheng et al. 2018). Globally, type 2 diabetes mellitus (T2DM) and its complications have contributed incredibility to the burden of mortality and health cost all over the world (Cai and Kang 2003).

Management of diabetes with no side effect is as yet a challenge to the medical system. Nowadays, available synthetic antidiabetic agents cause severe side effects such as hypoglycemic coma and hepatorenal disorders (Gupta et al. 2008). Furthermore, they are not safe

\footnotetext{
* Correspondence: weaam_gouda@yahoo.com; weaamgoudaali@gmail.com ${ }^{1}$ Biochemistry Department, National Research Centre, Cairo, Egypt Full list of author information is available at the end of the article
}

throughout pregnancy (Abo et al. 2008). Therefore, the more efficient and safer anti-diabetic agents are still under research. Currently, numerous plant metabolites are being effectively intended for the recovery of various diseases. Regarding to estimation, $80 \%$ of the world's populace depended on plants for their medication. The utilization of the medicinal plants is rising in several countries where $35 \%$ of drugs have natural products and ethno botanical information shows that plant species played a role in the diabetic management (Van Huyssteen et al. 2011).

Curcumin, the active ingredient from the spice turmeric, is an effective anti-inflammatory and antioxidant agent with antimicrobial, hepatoprotective, and anticarcinogenic characteristics (Rahmani et al. 2018). Moreover, curcumin has a valuable effect on blood glucose in diabetics and elevates gastric mucosal production (Nasri et al. 2014). The turmeric rhizomes have been demonstrated to induce antidiabetic properties as its alcohol extract have active ingredients lowering blood glucose in alloxan rendered 
diabetic rats. Although, the curcumin antidiabetic effects have been studied extensively, the research studies are still contradictory. Also, the molecular researches concerning the curcumin effect on the gene expression of insulin and insulin receptors have not been clearly elucidated ( $\mathrm{Yu}$ et al. 2013). Upon this basis, our work aims to develop a powerful natural antidiabetic agent using nanotechnology. This can be fulfilled via studying the effect of nano-curcumin in treating streptozotocin (STZ)-induced diabetic rats to evaluate its effect on gene expression of insulin and insulin receptor.

\section{Materials and methods}

\section{Experimental animals}

A total of 40 adult female albino rats weighing between $200 \pm 20$ g were maintained as performed by national guidelines and protocols, approved by the National Research Centre Ethics Committee. They were classified into four groups and housed in clean and disinfected cages. Commercial basal diet and water were provided ad libitum. Rats were subjected to natural photoperiod of $12 \mathrm{~h}$ light:dark cycle throughout the experimental period (3 weeks). All rats received basal diet for 1 week before the start of the experiment for adaptation and to ensure normal growth and behavior.

\section{Preparation of curcumin nanoparticles}

Nanoparticles loaded with curcumin were prepared by a modified emulsion-diffusion-evaporation method, previously reported (Shirsath et al. 2017). Briefly, curcumin $(4 \mathrm{~g})$ were dissolved in $100 \mathrm{ml}$ of acetone and allowed to ultrasonication for $30 \mathrm{~min}$ at $65{ }^{\circ} \mathrm{C}$ covered by aluminum foil and stirred at $85 \mathrm{rpm}$ for $1 \mathrm{~h}$ on $55{ }^{\circ} \mathrm{C}$ in fuming hood then put in an oven for $30 \mathrm{~min}$ at $50{ }^{\circ} \mathrm{C}$ to ensure the complete evaporation of the organic solvent (Soetikno et al. 2013).

\section{Induction of diabetes}

Diabetes was induced by administering intraperitoneal injection of a freshly prepared solution of streptozotocin (STZ) (sigma, St. Louis, MO, USA) $(50 \mathrm{mg} / \mathrm{kg}$ b. wt.) in $0.05 \mathrm{M}$ cold citrate buffer $(\mathrm{pH} 4.5)$ to the overnight fasted rats. Because of the instability of STZ in aqueous media, the solution was made using cold citrate buffer immediately before administration (Wei et al. 2003). Control rats were injected with saline alone. Every 2 days, fasting blood glucose levels were monitored using an accu-check blood glucose meter (Roche Diagnostics). Animals having blood glucose levels $145 \mathrm{mg} / \mathrm{dl}$ were excluded from the experiment and animals having blood glucose values above $200 \mathrm{mg} / \mathrm{dl}$ for seven consecutive days after STZ injection were considered as diabetic rats.

\section{Experimental design}

Rats were divided into four groups (ten rats for each). The first group (group I) served as negative control, non-diabetic rats, fed standard diet. Rats of the second group (group II) served as positive control, rendered diabetic by administering intraperitonial injection of a freshly prepared solution of STZ (50 mg/kg b. wt.) in $0.05 \mathrm{M}$ cold citrate buffer ( $\mathrm{pH}$ 4.5). Rats of the third group (group III) rendered diabetic and received nano-curcumin at a dose of $15 \mathrm{mg} / 5 \mathrm{ml} / \mathrm{kg} \mathrm{b}$. wt. The fourth group (group IV) rendered diabetic and treated with Diamicron at a dose of $15 \mathrm{mg} / 5 \mathrm{ml} / \mathrm{kg}$ b.wt. All formulations were given orally for 3 weeks using an oral gavages needle.

\section{Samples collection and estimation of glucose and insulin levels}

After 21 days from diabetes induction, blood samples were collected from the fasted rats of four groups by snipping tail with sharp razor and were centrifuged at $3000 \mathrm{rpm}$ for $10 \mathrm{~min}$ to measure glucose and insulin levels and this called (Start). Blood glucose level was then measured immediately by the glucose oxidase method using kit purchased from Stanbio (TX, USA). Blood samples were collected and serum was separated and stored at $-80{ }^{\circ} \mathrm{C}$ until further analysis of kidney and liver functions by using ALT/ SGPT Liqui-UV ${ }^{\circ}$ and AST/ SGOT Liqui-UV ${ }^{\circ}$ (Rate) purchased from Stanbio (TX, USA). Serum insulin concentrations were assayed by an enzyme-linked immunosorbent assay (ELISA) according to the method of Temple et al., using kit purchased from DRG international, Inc. (NJ, USA). At the end of the experiment, two samples of liver and pancreas tissues were collected from all groups; the first sample was fixed in $10 \%$ buffered neutral formalin solution, blotted, weight, and processed for immunohistochemical and histological study. The second sample was stored in liquid nitrogen till real-time PCR analysis.

\section{Histological study}

The collected specimens from the pancreas and liver were fixed in $10 \%$ buffered neutral formalin solution, dehydrated in gradual ethanol (70-100\%), cleared in xylene, and embedded in paraffin. Five-micron thick paraffin sections were prepared then stained with hematoxylin and eosin dyes for microscopic examination.

\section{Total RNA isolation}

Liver tissues (approximately $50 \mathrm{mg}$ of tissue per sample) were immediately added to $1 \mathrm{ml}$ of TriZol reagent (Invitrogen, Germany) and homogenized. 
One milliliter of the tissue homogenate was transferred to a microfuge tube and total RNA was extracted by adding $0.2 \mathrm{ml}$ chloroform. Afterwards, samples were vortexed vigorously for $15 \mathrm{~s}$ and incubated at room temperature for $3 \mathrm{~min}$. After centrifugation $(12,000 \times g / 15 \mathrm{~min})$ at $4{ }^{\circ} \mathrm{C}$, the aqueous phase containing RNA was transferred into new tubes. RNA was precipitated by mixing the aqueous phase with $0.5 \mathrm{ml}$ isopropyl alcohol and incubated at room temperature for $10 \mathrm{~min}$. After centrifugation at 12, $000 \times g$ for $10 \mathrm{~min}$ at $4{ }^{\circ} \mathrm{C}$, RNA pellets were washed by mixing and vortexing with $1 \mathrm{ml}$ of $75 \%$ ethanol. After centrifugation $(7500 \times \mathrm{g} / 5 \mathrm{~min})$ at $4{ }^{\circ} \mathrm{C}$, RNA pellets were resuspended in nuclease-free water (Invitrogen, Germany). The purity of RNA at 260/ 280 OD ratio and RNA integrity was evaluated spectrophotometrically. Only high purity samples (OD 260/280 >1.8) were subjected to further manipulation.

\section{Reverse transcription reaction}

cDNA was prepared from RNA samples according to RevertAid $^{\text {tw }}$ First Strand cDNA Synthesis Kit (Fermentas, Germany) by using Thermal Cycler. Briefly, total RNA were activated at $70{ }^{\circ} \mathrm{C}$ for $10 \mathrm{~min}$ and $20 \mu \mathrm{l}$ reaction mix were made of $4 \mu \mathrm{l} \mathrm{MgCl}, 2 \mu \mathrm{l}$ of reverse transcription $10 \times$ buffer, $2 \mu \mathrm{l}$ of dNTP mixture $(10 \mathrm{mM}), 0.5 \mu \mathrm{l}$ of oligo-dT primers, $50 \mathrm{IU}$ of MuLV reverse transcriptase enzyme, $5 \mu \mathrm{g}$ RNA and nuclease-free water to a final volume of $20 \mu \mathrm{l}$. Then the reaction was incubated at $42{ }^{\circ} \mathrm{C}$ for $60 \mathrm{~min}$ followed by incubation at $99{ }^{\circ} \mathrm{C}$ for $5 \mathrm{~min}$. cDNA was diluted up to $100 \mu \mathrm{l}$ with nucleasefree water for PCR amplification.

\section{Real-time PCR}

Real-time RT-PCR was performed using SYBR ${ }^{\circ}$ Premix Ex TaqTM (TaKaRa, Biotech. Co. Ltd.). The $25 \mu \mathrm{l}$ reaction for each examined gene was prepared from $12.5 \mu \mathrm{l}$ of master mix; $0.5 \mu \mathrm{l}$ forward primer $(0.2 \mu \mathrm{mol})$; $0.5 \mu \mathrm{l}$ revers primer $(0.2 \mu \mathrm{mol}) ; 5 \mu \mathrm{l} \mathrm{cDNA}$ of the sample; and $6.5 \mu \mathrm{l}$ of nuclease-free water. The reaction program was $95{ }^{\circ} \mathrm{C}$ for $3 \mathrm{~min}, 40$ cycles of $95{ }^{\circ} \mathrm{C}$ for $15 \mathrm{~s}$, followed by $55^{\circ} \mathrm{C}$ for $30 \mathrm{~s}$ and $72{ }^{\circ} \mathrm{C}$ for $30 \mathrm{~s}$ with final step consisted of 71 cycles which started at $60{ }^{\circ} \mathrm{C}$ and then increased about $5{ }^{\circ} \mathrm{C}$ every $10 \mathrm{~s}$ up to $95^{\circ} \mathrm{C}$. For each gene examined samples from each cDNA analyzed by RT-PCR using StepOne Real-Time PCR System (Applied Biosystems ${ }^{\mathrm{Tm}}$, USA). At the end of each qRT-PCR, a melting curve analysis was performed at $95{ }^{\circ} \mathrm{C}$ to check the quality of the used primers. Each experiment included a distilled water control. The sequences of specific primers for qRT-PCR amplification of the insulin and insulin receptor genes used are listed as follow:

\begin{tabular}{ll}
\hline Gene & Primer sequences (5'-'3) \\
Insulin & F-CCT GTT GGT GCA CTT CCT AC \\
& R-TGC AGT AGT TCT CCA GCT GC \\
Insulin receptor & F-TTCATTCAGGAAGACCTCGA \\
& R-AGGCCAGAGATGACAAGTGAC \\
$\beta$-actin & F-GGTATGGAATCCTGTGGCATCCATGAAA \\
& R-GTGTAAAACGCAGCTCAGTAACAGTCCG \\
\hline
\end{tabular}

\section{Statistical analysis}

All data was presented as mean \pm standard deviation. One-way ANOVA was used for multiple post-hoc comparisons. All tests were performed using the statistical package for the social science program (SPSS version 17.0). Percentage difference, representing the percentage of the variation with respect to the corresponding control group, was also calculated using the following formula: \%change $=$ treated - control value / control value *100. The relative gene expression of target genes (insulin and insulin receptor) in comparison to the $\beta$-actin reference gene was calculated using the $2^{-\triangle \Delta C T}$ method as follows:

$$
\begin{aligned}
\Delta \mathrm{C}_{\mathrm{T}(\text { test })} & \left.=\mathrm{C}_{\mathrm{T}(\text { target,test })}-\mathrm{C}_{\mathrm{T}(\text { reference,test })}, \Delta \mathrm{C}_{\mathrm{T}} \text { (calibrator }\right) \\
& =\mathrm{C}_{\mathrm{T}(\text { target,calibrator })}-\mathrm{C}_{\mathrm{T}(\text { reference,calibrator })}, \Delta \Delta \mathrm{CT} \\
& =\Delta \mathrm{C}_{\mathrm{T}(\text { Test })}-\Delta \mathrm{C}_{\mathrm{T}(\text { calibrator })}
\end{aligned}
$$

\section{Results}

\section{Curcumin nanoparticles characterization}

Nanoparticles with encapsulated curcumin have been prepared successfully using the emulsion diffusion evaporation method. X-ray diffraction (XRD) pattern of the curcumin nanoparticles reveals single phase with no extra peaks indicating the high purity of the sample under investigation. The particle average size of curcumin-encapsulated nanoparticles was $32 \mathrm{~nm}$ (Fig. 1). The electron micrographs indicated the clear platelets with hexagonal shape, slightly agglomerated in a chain like network (Fig. 1). This result agrees well with that calculated from XRD.

The effect of nano-curcumin on blood glucose concentration of STZ diabetic rats was shown in Table 1. After injection of STZ, the mean values of blood glucose levels in untreated diabetic rats (group II) were remained high $348.8 \mathrm{mg} / \mathrm{dl}$ during the entire period of the study, which were significantly higher $(P<$ 0.05) than those of the non-diabetic controls $(102.58 \mathrm{mg} / \mathrm{dl})$. The high level of glucose in diabetic rats was reduced as result of Diamicron and curcumin administration (149.5 $\mathrm{mg} / \mathrm{dl}$ and $158.75 \mathrm{mg} / \mathrm{dl})$ respectively. In addition, the effect of nano-curcumin on blood insulin level of STZ diabetic rats was significantly different from diabetic untreated rats. 

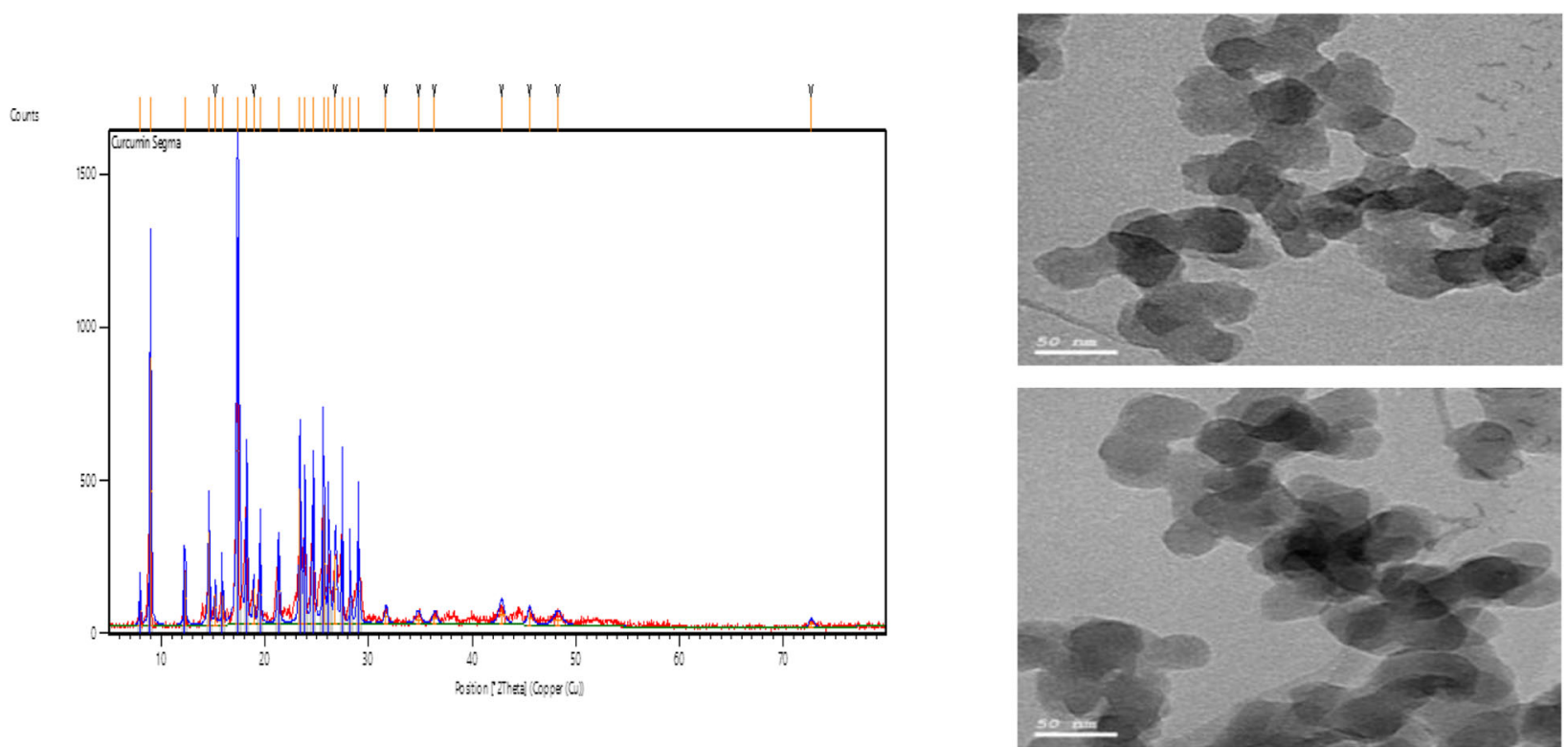

Fig. 1 Pancreas pathology. X-ray diffraction pattern of curcumin particles after annealing at $25^{\circ} \mathrm{C}$ (left panel) and transmission electron microscopy images (right panel) of curcumin nanoparticles

In Table 2, the induction of nano-curcumin to diabetic rats indicated that AST, ALT, urea, and creatinine were not statistically significantly $(P>0.05)$ different when compared to diabetic untreated rats and control nondiabetic rats.

\section{Histopathological examinations}

The histopathological changes of female rats treated with STZ showed marked reduction and deformity in the size and shape of islets of Langerhans with marked alterations in the histoarchitecture of the islets exhibited remarkable necrotic modifications with minimal cells and infiltration of connective tissue, also the exocrine part of pancreas indicated swelling of acini cells with noticeable vacuolization and fatty changes. After the administration of nanocurcumin; the histoarchitecture of pancreatic islets exposed well developed with marked cellular regeneration and mild central necrotic modifications and peripheral fatty changes (Fig. 2). Moreover, the liver indicated mild necrotic changes, moderate fatty and balloon alterations, dilated blood sinusoids, and normal appearance and distribution of Kuppfer cells (Fig. 3).

\section{Immunohistochemical insulin staining}

Immunohistochemical insulin staining showed marked reaction with negative control and nano-curcumintreated groups, although indicated mild positive reaction with rendered diabetic group by STZ (Fig. 4).

Table 1 Effects of nano-curcumin and Diamicron on glucose, insulin, and glycated hemoglobin of Streptozotocin-induced diabetic rats

\begin{tabular}{|c|c|c|c|c|}
\hline Variables & NC (group I) & DC (group II) & Diab-Diam (group III) & Diab-Cur (group IV) \\
\hline \multicolumn{5}{|c|}{ Glucose (mg/dl) } \\
\hline Start & $104.67 \pm 8.4$ & $243^{a} \pm 12.6$ & $241.67^{a} \pm 6.5$ & $244.75^{a} \pm 8$ \\
\hline Final & $102.58 \pm 4.9$ & $348.8^{\mathrm{a}} \pm 11.3$ & $149.5^{a b} \pm 5$ & $158.75^{\mathrm{ab}} \pm 5.08$ \\
\hline \multicolumn{5}{|c|}{ Insulin (mIU/ml) } \\
\hline Start & $13.26 \pm 0.22$ & $9.04^{a} \pm 0.23$ & $9.39^{a} \pm 0.27$ & $9.04^{a} \pm 0.37$ \\
\hline Final & $13.6 \pm 0.29$ & $7.95^{a} \pm 0.54$ & $11.22^{\mathrm{ab}} \pm 0.28$ & $10.92^{\mathrm{ab}} \pm 0.38$ \\
\hline $\mathrm{HbA1C}(\%)$ & $5.97 \pm 0.36$ & $8.96^{a} \pm 0.28$ & $7^{\mathrm{ab}} \pm 0.40$ & $7.25^{\mathrm{ab}} \pm 0.27$ \\
\hline
\end{tabular}

Values are expressed as mean \pm SD for each group, $n=10$ for each group

NC negative control, DC diabetic control group, Diab-Diam treatment group (fed a normal diet plus diamicron), Diab-Cur treatment group (fed a normal diet plus curcumin)

${ }^{a}$ Values are significantly different from negative control $(P<0.05)$

${ }^{b}$ Values are significantly different from diabetic control group $(P<0.05)$ 
Table 2 Effects of nano-curcumin and Diamicron on liver and kidney functions of Streptozotocin-induced diabetic rats

\begin{tabular}{lllll}
\hline Variables & NC (group I) & DC (group II) & Diab-Diam (group III) & Diab-Cur (group IV) \\
\hline AST (U/L) & $22.83 \pm 6.45$ & $22.91 \pm 4.59$ & $20 \pm 4.89$ & $19.66 \pm 5.93$ \\
ALT (U/L) & $22.08 \pm 5.7$ & $21.58 \pm 3.9$ & $20.5 \pm 5.76$ & $19.91 \pm 5.66$ \\
Urea $(\mathrm{mg} / \mathrm{dl})$ & $21.91 \pm 4.57$ & $23.33 \pm 4.04$ & $22.58 \pm 3.04$ & $22.08 \pm 3.30$ \\
Creatinine $(\mathrm{mg} / \mathrm{dl})$ & $0.74 \pm 0.11$ & $0.70 \pm 0.14$ & $0.70 \pm 0.14$ & $0.69 \pm 0.13$ \\
\hline
\end{tabular}

Values are expressed as mean \pm SD for each group, $n=10$ for each group

NC negative control, DC diabetic control group, Diab-Diam treatment group (fed a normal diet plus Diamicron), Diab-Cur treatment group (fed a normal diet plus curcumin)

\section{Effect of curcumin nanoparticles on expression of insulin and insulin receptor genes}

The insulin and insulin receptor gene expressions in liver and pancreas tissues of diabetic rats induced by STZ are illustrated. Additionally, effect of curcumin nanoparticles on the expression of insulin and insulin receptor genes was determined using quantitative RTPCR (Figs. 5 and 6).

The results showed that liver and pancreas tissues of DM rats exhibited significantly higher expression levels of insulin mRNAs $(P<0.01)$ in comparison to other treated rats (Fig. 5). Moreover, the pancreas tissues revealed higher expression of insulin genes than the liver tissues of DM rats. On the other hand, treatment of DM rats with curcumin nanoparticles decreased significantly $(P<0.05)$ the expression levels of insulin in liver and pancreas tissues compared with those in DM rats.

Regarding the insulin receptor gene, the results indicated that the expression levels in pancreas tissues were significantly higher than those in liver tissues (Fig. 6). Moreover, the expression levels of insulin receptor gene in liver and pancreas tissues of DM rats were highly increased than those in other treated groups. However, treatment of DM rats with curcumin nanoparticles decreased significantly $(P<0.05)$ the expression levels of insulin receptor in liver and pancreas tissues compared with those in DM rats.

\section{Discussion}

Diabetes mellitus (DM) is a group of syndromes recognized by hyperglycemia, alteration of proteins, lipids and carbohydrates metabolism, and elevated the risk of vascular complications that are owing to an insufficient of insulin secretion. Additionally, it could take place when the insulin receptors are resistant to the circulating insulin functions (ADA 2010).

Curcumin is nearly water-insoluble and has low bioavailability (Modasiya and Patel 2012); a possible solution to this problem would be the development of formulations of curcumin nanoparticles to enhance its stability (Mohanty and Sahoo 2010). The higher watersolubility might be due to a larger surface area in contact with the solvent. Both the curcumin and the nanocurcumin have the same chemical structure. The nanocurcumin aqueous dispersion had an antimicrobial effect stronger than the curcumin (Bhawana Basniwal et al. 2011). At the start of the experiment, the mean values of blood glucose levels in untreated diabetic rats were still high $(348.8 \mathrm{mg} / \mathrm{dl})$ through the entire period of the study, which were significantly higher than those of the nondiabetic controls $(102.58 \mathrm{mg} / \mathrm{dl})$. At the end of the experiment, the elevated level of glucose in diabetic rats was reduced as a result of Diamicron and nano-curcumin administration (57.1\% and 54.5\%) respectively (Table 1). Additionally, the effect of nano-curcumin on insulin level

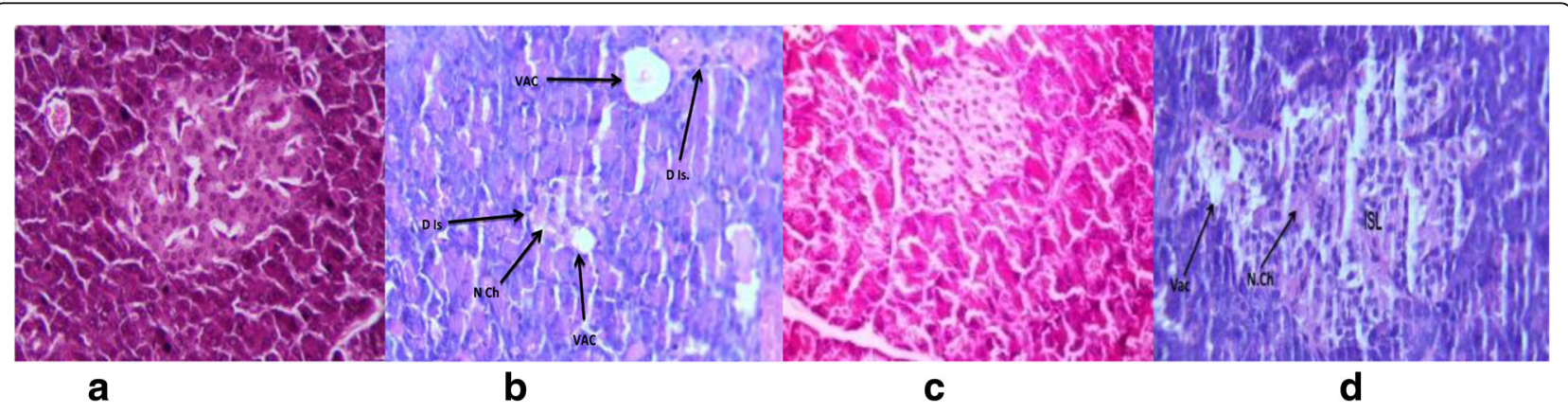

Fig. 2 Liver pathology. Histopathological graphs show a photomicrograph showing the normal histological architecture of the control rat pancreas, normal acinar structure with normal islets. b Pancreas of positive control group induced diabetic with STZ, showing marked reduction in islets of Langerhans with marked degenerative changes and necrotic tissue; all the islets acini showing marked atrophy degenerative and vaculation changes. c Pancreas of Diamicron-treated group showing restoration of normal size of islets of Langerhans with normal endocrine cell distribution with mild necrotic tissue. $\mathbf{d}$ Photomicrograph of pancreas of nano-curcumin-treated group showing moderate restoration of cells of islets of Langerhans with mild necrotic changes 


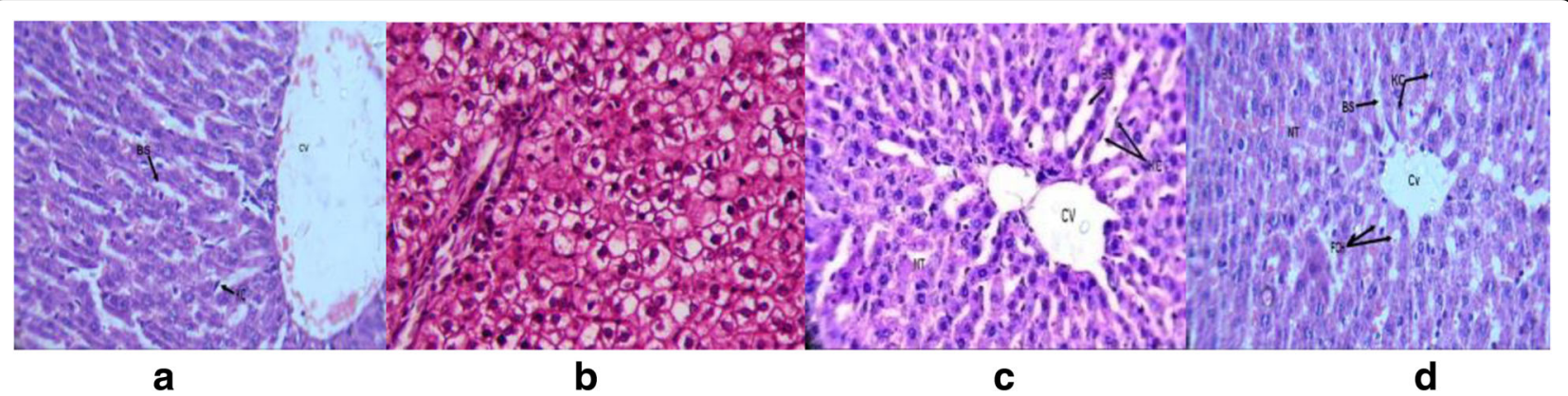

Fig. 3 Histopathological graphs showing a liver of normal rat (negative control) with normal blood sinusoids, normal histoarchitecture, and hepatic cords with normal appearance and distribution of Kuppfer cells (KC). b A photomicrograph of liver of diabetic rat showing Kupffer cells activation and cytoplasmic vacuolization of hepatocytes, dilatation of liver sinusoids, and some necrotic changes of liver tissue. $\mathbf{c}$ Liver of Diamicron-treated group showing moderate blood sinusoids (BS) with mild increased of Kupffer cells, mild necrotic changes, normal tissue histoarchitecture, and normal hepatic cords. $\mathbf{d}$ Liver of curcumin-treated group showing normal tissue histoarchitecture with mild dilatation of blood sinusoids, mild increase in number and distribution of Kuppfer cells, moderate fatty changes (FCH), and moderate necrotic changes (NT)

of STZ diabetic rats was significantly different from diabetic untreated rats. Similar to the present findings, hyperglycemia could be related to improvement of gluconeogenesis due to insulin deficiency (Hussain 2002; Yao et al. 2006; Sellamuthu et al. 2009). Prior studies have reported that plant extracts enhanced hypoglycemic properties which consecutively reversed STZ-induced hyperglycemia (Okonkwo and Okoye 2009; Luka and Tijjani 2013). Mafulul et al. (2013) suggested that the possible mechanism by which curcumin gives its hypoglycemic effect could be through stimulation of pancreatic insulin production from $\beta$ cells of islets of Langerhans or as a result of enhancement of blood glucose transport to peripheral tissue. Also, other possible mechanisms revealed by Youn et al. (2004) and Xi et al. (2007) that reducing insulin resistance and suppression of intestinal glucose intake are demonstrated. Curcumin might include biomolecules that was capable of modification or stimulation of insulin receptors, alteration of glucose transport protein structure, and could suppress insulin antagonist in the body (Igbakin and Oloyede 2009).
In the contrary, several investigators illustrated that curcumin has insignificant effect on blood glucose. Nishizono et al. (2000) found that the intragastric intake of curcumin $(200 \mathrm{mg} / \mathrm{kg}$. b. wt.) has no effect on serum glucose and insulin levels in STZ-induced diabetic rats for 14 days. Furthermore, Majithiya and Balaraman (2005) stated that oral administration of curcumin from 4 to 24 weeks $(200 \mathrm{mg} / \mathrm{kg}$ b. wt.) with no significant effect on blood glucose in STZ diabetic rats. The cause for these contradictory findings from different studies may be possibly attributable to different induction diabetes rodent models or various administration of curcumin or nano-curcumin.

In the present study, the results showed that liver and pancreas tissues of DM rats displayed significantly higher expression levels of insulin mRNAs as compared to other treated rats), the pancreas tissues revealed higher expression of insulin genes than the liver tissues of DM rats (Fig. 5). On the other hand, treatment of DM rats with curcumin nanoparticles decreased significantly the expression levels of insulin gene in liver

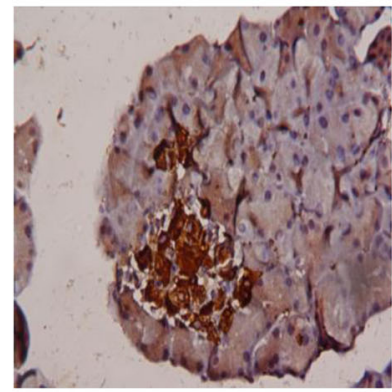

a

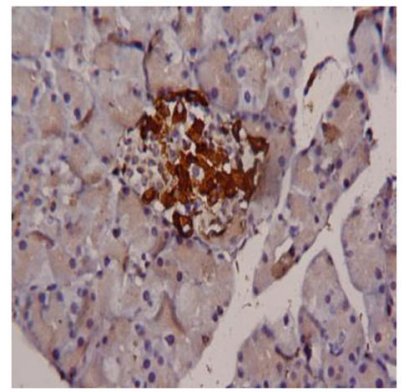

b

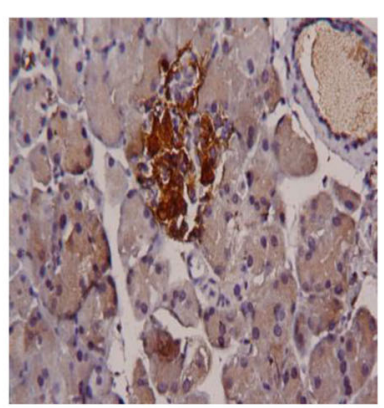

C

Fig. 4 Immunohistochemical graphs showing a negative control which shows marked immunohistochemical insulin positive reaction. b Diabetic model induced with STZ shows mild immunohistochemical insuline positivity distributed in the islets. c STZ-induced diabetic model treated with curcumin extract shows marked immunohistochemical insulin positivity 


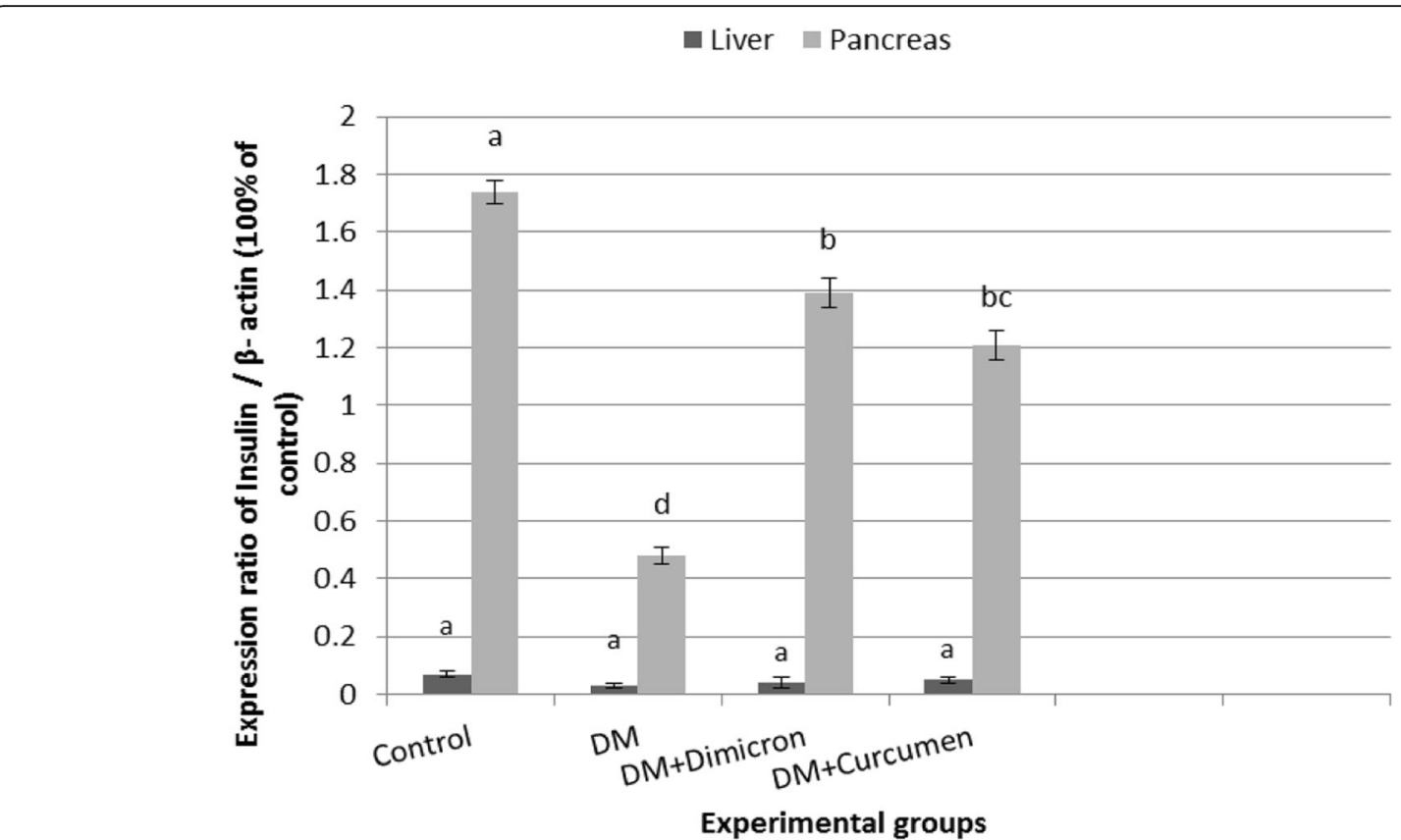

Fig. 5 The alterations of insulin-mRNA in liver and pancreas tissues collected from female DM rats treated with curcumin nanoparticles. ${ }^{\text {a,b,c }}$ Mean values \pm standard deviation within tissue with unlike superscript letters were significantly different $(P<0.05)$

and pancreas tissues compared with those in DM rats. Regarding the insulin receptor gene, the results indicated that the expression levels in pancreas tissues were clearly higher than those in liver tissues. The expression levels of insulin receptor gene in liver and pancreas tissues of DM rats were highly elevated than those in other treated groups. However, induction of DM rats with curcumin nanoparticles decreased significantly the expression levels of insulin receptor in liver and pancreas tissues compared with those in DM rats (Fig. 6). In the same line, a recent study by Hussein et al. (2014) evaluated the potential therapeutic effect of

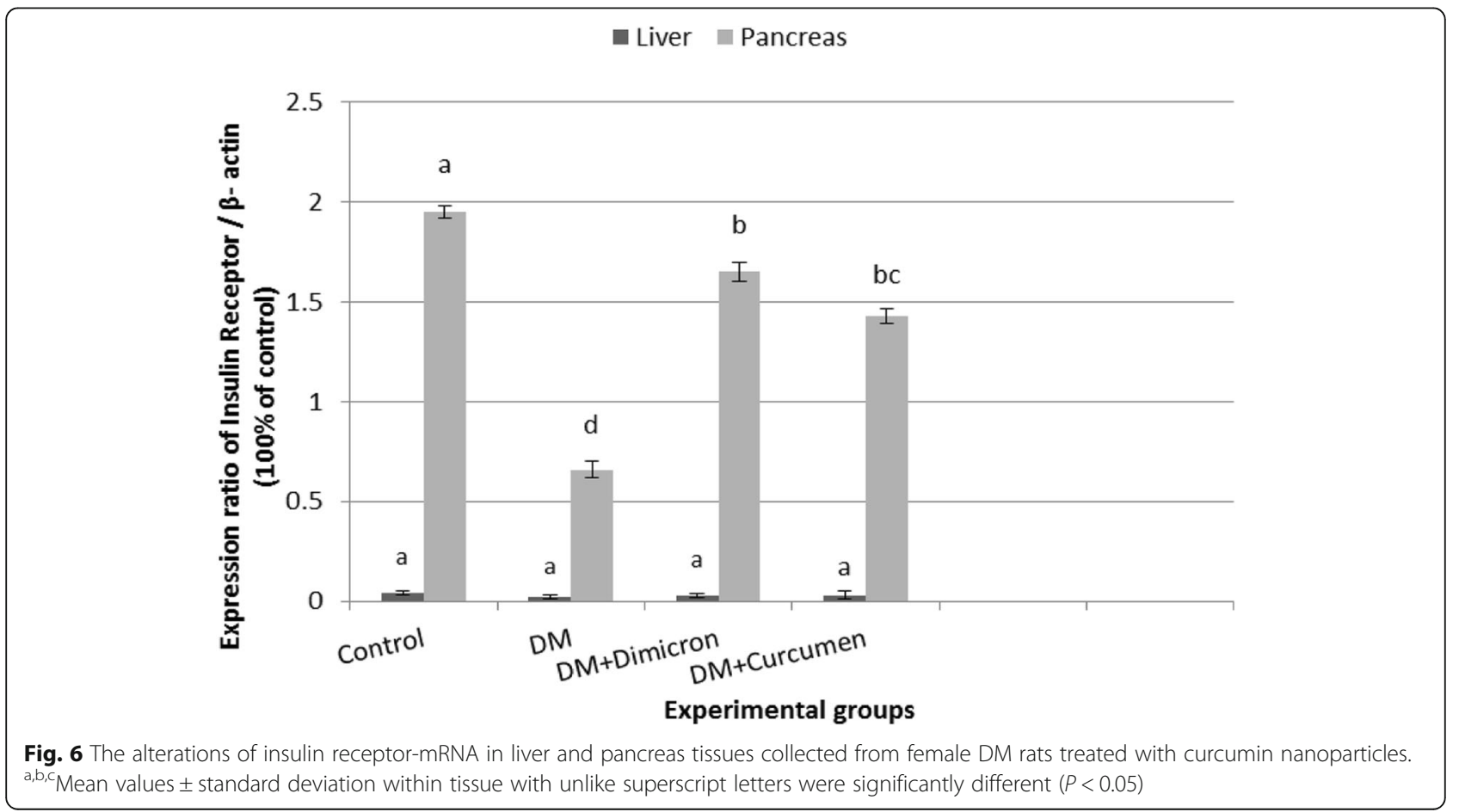


zinc oxide nanoparticles (ZnONPs) on STZ-rendered diabetic rats in addition to its associated effect to insulin treatment and the results pointed out that mRNA expression levels of insulin and insulin receptor genes appeared to rise in $\mathrm{ZnONPs}$ and insulin treated groups as compared to the diabetic non-treated group. Similarly, many studies exhibited the role of metals in glucose metabolism and the associations of their deficiencies with diabetes like Vanadium (Thompson et al. 2009), chromium (Wang and Cefalu 2010), and magnesium (Wells 2008) have been reported to act a role in the maintenance of blood sugar and have been involved in the treatment of diabetes.

Various experimental models of diabetes have been used to explain the effect of nano-curcumin on glycemia. In STZ-induced rats, oral administration of nano-curcumin in various doses prevented weight loss, reduced glucose and glycated hemoglobin A1c (HbA1c) levels, improved insulin sensitivity, and hypoinsulinemia (Peeyush et al. 2009; Na et al. 2011; Chuengsamarn et al. 2012). These findings are not surprising considering the effect of nano-curcumin on pancreatic cells and insulin sensitivity, which have been extensively studied (Chanpoo et al. 2010; Shehzad et al. 2011). Curcumin might increase islet viability by inhibiting the production of reactive oxygen species. This may be mediated by the inhibition of poly ADP-ribose polymerase- 1 activation and the normalization of pro-inflammatory cytokines (tumor necrosis factor $\alpha(\mathrm{TNF} \alpha)$, interleukin $1 \beta$ (IL-1 $\beta)$, and interferon- $\gamma$ ) and their inducement of nuclear factor kappa B (NF-kb) translocation without affecting normal islet function, which results in increased pancreatic glucose transporter-2 (GLUT 2) levels and glucose clearance (Seo et al. 2008). As a consequence of these two effects, pancreatic islet cell lymphocyte infiltration and destruction are decreased (Ran et al. 2011). Finally, curcumin increases the opening and motivation of anion channels and depolarizes the pancreatic $\beta$ cell membrane potential, which results in electronic activity and insulin secretion (Shimabukuro et al. 1998). In addition, curcumin is involved in the abnormal misfolding of human islet amyloid polypeptide and creation of pancreatic amyloid deposits (Liang et al. 2008). These stimulatory actions of curcumin might participate in hypoglycemia in diabetes. Additional positive effect of curcumin is the depression of circulating free fatty acids (FFAs). FFA-induced lipotoxicity is an essential contributor of insulin resistance. This mechanism has been proposed to deteriorate pancreatic $\beta$ cell function and impair the insulin signaling pathway during stimulation of NF-kb. Downstream products of the NF-kb pathway interfere with the transcription of insulin receptors and transporters thus impairing insulin sensitivity (Forbes and Cooper 2013).
Furthermore, our results exhibited marked restoration and regeneration of islets of Langerhans after induction with curcumin; this may be described as STZ does not destroy the intra-islet stem cell reserve in experimentally diabetic animals (Banerjee and Bhonde 2003). In support, Ianus et al. (2003) showed that bone marrow cells can differentiate into functionally competent pancreatic $\beta$ cells; thereby rationalizing for the cellbased approach in diabetic treatment. Since, staining with insulin antibody showed many variable sized and shaped islets with strong insulin positivity and no $C D$ 105-positive cells in pancreatic tissue or fat, the difference in the time of appearance of $\beta$ cells and insulin-positive cells may be due to there is no complete destruction of islets so there is rapid regeneration of islets of Langerhans after curcumin nanoparticles administration. In addition, Abdelaziz et al. (2013) stated that the histopathological and immunohistochemical examination informed the appearance of stem cells in the adipose tissue infiltrating the pancreatic tissues in diabetic rat receiving the curcumin nanoparticles and these cells were positive for CD105.

\section{Conclusions}

Given its valuable effects, safety, and cost-effectiveness, we propose that nano-curcumin may be contributed in diabetes treatment as natural hypoglycemic drugs. The induction of nano-curcumin decreased glucose concentration and increased the activities and gene expression of insulin and insulin receptor. Further researches are necessary to examine whether the cause of gene expression activation was owing to a direct effect of curcumin in the above-mentioned genes or because of the general effect of curcumin that leads to a chain of reactions that represent the observed variations.

\section{Abbreviations}

BS: Blood sinusoids; FCH: Fatty changes; FFAs: Free fatty acids; GLUT

2: Glucose transporter-2; IL-1 $\beta$ ), and interferon- $\gamma$ : Interleukin $1 \beta$; KC: Kuppfer cells; NT: Necrotic changes; RT: Reverse transcription; STZ: Streptozotocin;

T2DM): Type 2 diabetes mellitus; TNFa: Tumor necrosis factor $a$; XRD: X-ray diffraction; ZnONPs: Zinc oxide nanoparticles

\section{Acknowledgements \\ The authors thank Zoology Department, Faculty of Science, Helwan University and National Research Centre (NRC), Egypt. \\ Funding \\ The study is supported by Zoology Department, Faculty of Science, Helwan University and National Research Centre (NRC), Egypt.}

\section{Availability of data and materials}

All data generated or analysed during this study are included within the article.

\section{Authors' contributions}

All the authors have accepted responsibility for the entire content of this submitted manuscript and approved submission. 


\section{Ethics approval and consent to participate}

The study was done after obtaining approval from the ethical committee of the National Research Centre, Cairo, Egypt (registration number is 16-207).

\section{Consent for publication}

Not applicable for this study.

\section{Competing interests}

The authors declare that they have no competing interests.

\section{Publisher's Note}

Springer Nature remains neutral with regard to jurisdictional claims in published maps and institutional affiliations.

\section{Author details}

${ }^{1}$ Biochemistry Department, National Research Centre, Cairo, Egypt. ${ }^{2}$ Cell Biology Department, National Research Centre, Cairo, Egypt. ${ }^{3}$ Zoology Department, Faculty of Science, Helwan University, Helwan, Egypt.

\section{Received: 23 June 2019 Accepted: 15 July 2019}

Published online: 01 August 2019

\section{References}

Abdelaziz MT, El-Asmar MF, Rezq AM, Mahfouz SM, Wassef MA, Fouad HH, Ahmed HH, Taha FM (2013) The effect of a novel curcumin derivative on pancreatic islet regeneration in experimental type-1 diabetes in rats (long term study). Diabetol Metab Syndr 5:75

Abo KA, Fred-Jaiyesimi AA, Jaiyesimi AEA (2008) Ethnobotanical studies of medicinal plants used in the management of diabetes mellitus in South Western Nigeria. J Ethnopharmacol 115:67-71

ADA (2010) Diagnosis and classification of diabetes mellitus. Am Diabetes Assoc Diabetes Care 33:62-69

Banerjee M, Bhonde RR (2003) Islet generation from intra islet precursor cells of diabetic pancreas: in vitro studies depicting in vivo differentiation. JOP 4:137-145

Bhawana Basniwal RK, Buttar HS, Jain VK, Jain N (2011) Curcumin nanoparticles: preparation, characterization, and antimicrobial study. J Agric Food Chem 59(5):2056-2061

Cai L, Kang YJ (2003) Cell death and diabetic cardiomyopathy. Cardiovasc Toxicol 3:219-228

Chanpoo M, Petchpiboonthai H, Panyarachun B, Anupunpisit V (2010) Effect of curcumin in the amelioration of pancreatic islets in streptozotocin-induced diabetic mice. J Med Assoc Thail 93(6):152-159

Chuengsamarn S, Rattanamongkolgul S, Luechapudiporn R, Jirawatnotai S (2012) Curcumin extract for prevention of type 2 diabetes. Diabetes Care 35:2121-2127

Forbes JM, Cooper ME (2013) Mechanisms of diabetic complications. Physiol Rev 93:137-188

Gupta R, Bajpai GK, Johri S, Saxena AM (2008) An overview of Indian novel traditional medicinal plants with antidiabetic potentials. Afr J Trad CAM 5(1):1-17

Hussain HEMA (2002) Hypoglycemic, hypolipidemic and antioxidant properties of combination of curcumin from curcoma longa, Linn. And partiallt purified product from Abromaaugusta, Linn. In streptozotocin induced diabetes. Indian J Clin Biochem 17:33-43

Hussein SA, YA EL-S, El-Dawy K, Baz HA (2014) Evaluation of xinc oxide nanoparticles for insulin, insulin receptors and insulin receptors substrates gene expression in streptozotocin-induced diabetic rats. BVMJ 27(1):166-174

lanus A, Holz GG, Theise ND, Hussain MA (2003) In vivo derivation of glucose competent pancreatic endocrine cells from bone marrow without evidence of cell fusion. J Clin Invest 111:843-850

Igbakin AP, Oloyede OB (2009) Comparative studies on the hypoglycaemic, hypoproteinaemic, hypocholesterolaemic and hypolipidaemic properties of ethanolic and normal saline extracts of the root of Vernonia amygdalinain diabetic rats. Adv Environ Biol 3(1):33-38

Liang H, Yin B, Zhang H, Zhang S, Zeng Q, Wang J, Jiang X, Yuan L, Wang CY, Li Z (2008) Blockade of tumor necrosis factor (TNF) receptor type 1-mediated TNF alpha signaling protected Wistar rats from diet-induced obesity and insulin resistance. Endocrinol 149:2943-2951

Luka CD, Tijjani H (2013) Comparative studies of the aqueous extracts of Ocimumgratissimum, aloevera, brassica oleracea and ipomoea batatas on some biochemical parameters in diabetic rats. IOSR J Pharm Biol Sci 6(3):23-29

Mafulul SG, Luka CD, Kutshik RJ, Ojiakobi UP (2013) Protective effect of ethanolic extract of Gongronema latifolium leaves in Alloxan-induced diabetic rats. IOSR J Pharm Biol Sci 7(6):63-68 2319-7676

Majithiya JB, Balaraman R (2005) Time-dependent changes in antioxidant enzymes and vascular reactivity of aorta in streptozotocin induced diabetic rats treated with curcumin. J Cardiovasc Pharmacol 46:697-705

Modasiya MK, Patel VM (2012) Studies on solubility of curcumin. Int J of Pharm \& Life Sci 3(3):1490-1497

Mohanty C, Sahoo SK (2010) The in vitro stability and in vivo pharmacokinetics of curcumin prepared as an aqueous nanoparticulate formulation. Biomaterials 31(25):6597-6611

Na LX, Zhang YL, Li Y, Liu LY, Li R, Kong T, Sun CH (2011) Curcumin improves insulin resistance in skeletal muscle of rats. Nutr Metab Cardiovasc Dis 21:526-533

Nasri H, Sahinfard N, Rafieian M, Rafieian S, Shirzad M, Rafieian-kopaei M (2014) Turmeric: a spice with multifunctional medicinal properties. J HerbMed Plarmacol 3(1):5-8

Nishizono S, Hayami T, Ikeda I, Imaizumi K (2000) Protection against the diabetogenic effect of feeding tert-butylhydroquinone to rats prior to the administration of streptozotocin. Biosci Biotechnol Biochem 64:1153-1158

Okonkwo PO, Okoye ZS (2009) Hypoglycaemic effects of the aqueous extract of Newbouldialaevis root in rats. Int J Biol Chem Sci 3(5):998-1004

Peeyush KT, Gireesh G, Jobin M, Paulose CS (2009) Neuroprotective role of curcumin in the cerebellum of streptozotocin-induced diabetic rats. Life Sci 85:704-710

Rahmani AH, Alsahli MA, Aly SM, Khan MA, Aldebasi YH (2018) Role of curcumin in disease prevention and treatment. Adv Biomed Res 7:38

Ran C, Zhao W, Moir RD, Moore A (2011) Non-conjugated small molecule FRET for differentiating monomers from higher molecular weight amyloid beta species. PLoS One 6:e19362

Sellamuthu PS, Muniappan BP, Perumal SM, Kandasamy M (2009) Antihyperglycemic effect of mangiferin in streptozotocin induced diabetic rats. J Health Sci 55:206-214

Seo Kl, Choi MS, Jung UJ, Kim HJ, Yeo J, Jeon SM, Lee MK (2008) Effect of curcumin supplementation on blood glucose, plasma insulin, and glucose homeostasis related enzyme activities in diabetic $\mathrm{db} / \mathrm{db}$ mice. Mol Nutr Food Res 52:995-1004

Shehzad A, Ha T, Subhan F, Lee YS (2011) New mechanisms and the antiinflammatory role of curcumin in obesity and obesity-related metabolic diseases. Eur J Nutr 50:151-161

Shimabukuro M, Zhou YT, Levi M, Unger RH (1998) Fatty acid-induced beta cell apoptosis: a link between obesity and diabetes. Proc Natl Acad Sc U S A 95:2498-2502

Shirsath SR, Sable SS, Gaikwad SG, Sonawane SH, Saini DR, Gogate PR (2017) Intensification of extraction of curcumin from Curcuma amada using ultrasound assisted approach: effect of different operating parameters. Ultrason Sonochem 38:437-445

Soetikno V, Sari FR, Sukumaran V, Lakshmanan AP, Harima M, Suzuki K, Kawachi H, Watanabe K (2013) Curcumin decreases renal triglyceride accumulation through AMPK-SREBP signaling pathway in streptozotocininduced type 1 diabetic rats. Nutr Biochem 24:796-802

Thompson KH, Lichter J, LeBel C, Scaife MC, McNeill JH, Orvig C (2009) Vanadium treatment of type 2 diabetes: a view to the future. J Inorg Biochem 103(4):554-558

Van Huyssteen M, Milne PJ, Campbell EE, van de Venter M (2011) Antidiabetic and cytotoxicity screening of five medicinal plants used by traditional African health practitioners in the Nelson Mandela metropole, South Africa. Afr J Tradit Complement Altern Med 8(2):150-158

Wang ZQ, Cefalu WT (2010) Current concepts about chromium supplementation in type 2 diabetes and insulin resistance. Curr Diab Rep 10(2):145-151

Wei M, Ong L, Smith MT, Ross FB, Schmid K, Hoey AJ, Burstow D, Brown L (2003) The streotozotocin-diabetic rat as model of the chronic complication of human diabetes. Heart lung circ 12(1):44-50

Wells IC (2008) Evidence that the etiology of the syndrome containing type 2 diabetes mellitus results from abnormal magnesium metabolism. Can J Physiol Pharmacol 86(1-2):16-24

Xi L, Qian Z, Xu G, Zhou C, Sun S (2007) Crocetin attenuates palmitate-induced insulin insensitivity and disordered tumor necrosis factor and adiponectin expression in rat adipocytes. Br J Pharmacol 151:610-617 
Yao XH, Chen L, Nyomba BLG (2006) Adult rats prenatally exposed to ethanol have increased gluconeogenesis and impaired insulin response of hepatic gluconeogenic. Genes J Applied Physiol 100:642-648

Youn JY, Park HY, Cho KH (2004) Antihyperglycemic activity of Commelina Communis L. inhibition of a-glucosidase. Diabetes Res Clin Pract 66 S149-S155

Yu W, Wu J, Cai F, Xiang J, Zha W, Fan D, Guo S, Ming Z, Liu C (2013) Curcumin alleviates diabetic cardiomyopathy in experimental diabetic rats. PLoS One 7:e52013

Zheng J, Cheng J, Zheng S, Feng Q, Xiao X (2018) Curcumin, a polyphenolic curcuminoid with its protective effects and molecular mechanisms in diabetes and diabetic cardiomyopathy. Front Pharmacol 9:472

\section{Submit your manuscript to a SpringerOpen ${ }^{\circ}$ journal and benefit from:}

- Convenient online submission

- Rigorous peer review

- Open access: articles freely available online

- High visibility within the field

- Retaining the copyright to your article

Submit your next manuscript at $\boldsymbol{\nabla}$ springeropen.com 